2000s-10

\title{
Productivity Trends and Employment across Industries in Canada
}

Pierre Mohnen, Thijs ten Raa

Série Scientifique
Scientific Series

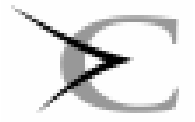




\section{CIRANO}

Le CIRANO est un organisme sans but lucratif constitué en vertu de la Loi des compagnies du Québec. Le financement de son infrastructure et de ses activités de recherche provient des cotisations de ses organisationsmembres, d'une subvention d'infrastructure du ministère de la Recherche, de la Science et de la Technologie, de même que des subventions et mandats obtenus par ses équipes de recherche.

CIRANO is a private non-profit organization incorporated under the Québec Companies Act. Its infrastructure and research activities are funded through fees paid by member organizations, an infrastructure grant from the Ministère de la Recherche, de la Science et de la Technologie, and grants and research mandates obtained by its research teams.

\section{Les organisations-partenaires / The Partner Organizations}

•École des Hautes Études Commerciales

-École Polytechnique

-Université Concordia

-Université de Montréal

-Université du Québec à Montréal

-Université Laval

-Université McGill

-MEQ

-MRST

-Alcan Aluminium Ltée

-Banque Nationale du Canada

-Banque Royale du Canada

-Bell Québec

-Développement des ressources humaines Canada (DRHC)

-Fédération des caisses populaires Desjardins de Montréal et de l'Ouest-du-Québec

-Hydro-Québec

-Imasco

-Industrie Canada

-Raymond Chabot Grant Thornton

-Téléglobe Canada

-Ville de Montréal

(C) 2000 Pierre Mohnen et Thijs ten Raa. Tous droits réservés. All rights reserved.

Reproduction partielle permise avec citation du document source, incluant la notice ().

Short sections may be quoted without explicit permission, provided that full credit, including $(\odot$ notice, is given to the source.

Ce document est publié dans l'intention de rendre accessibles les résultats préliminaires de la recherche effectuée au CIRANO, afin de susciter des échanges et des suggestions. Les idées et les opinions émises sont sous l'unique responsabilité des auteurs, et ne représentent pas nécessairement les positions du CIRANO ou de ses partenaires.

This paper presents preliminary research carried out at CIRANO and aims at encouraging discussion and comment. The observations and viewpoints expressed are the sole responsibility of the authors. They do not necessarily represent positions of CIRANO or its partners. 


\title{
Productivity Trends and Employment across Industries in Canada*
}

\author{
Pierre Mohnen ${ }^{\dagger}$, Thijs ten Raa
}

Résumé / Abstract

Cette étude examine le paradoxe de la croissance relative de l'emploi et de la décroissance relative de la productivité dans les secteurs des services au Canada au cours de la période allant de 1961 à 1992. Ce phénomène est apparamment en contradiction avec le malaise de Baumol - «Baumol disease »-, qui prédit au contraire une baisse de l'activité dans les services à cause de leur performance médiocre en matière de productivité, qui devrait se réfléter dans des prix relatifs plus élevés. En résumé, nous concluons que le malaise de Baumol dans les services au Canada est mineur une fois que l'on inclut le capital dans la mesure de la productivité. Par contre, la part des services dans la demande finale domestique ne suit pas l'évolution des parts de l'emploi et de la valeur ajoutée. Et pourtant, la part des services dans la demande finale domestique augmente et ceci reste une énigme. Une explication possible serait un déplacement de l'innovation vers les services et, relié à cela, un déplacement des préférences vers les services. Les données sur la distribution de la R-D, pour ce qu'elles valent, tendraient à soutenir cet argument.

This paper addresses the paradox between an increasing share of employment and a lower productivity growth of Canadian services vis-à-vis the rest of the economy in the period spanning the three decades from 1961 to 1992. It attempts to reconcile this apparent contradiction with the so-called Baumol disease, which predicts a decline in the share of services given their relative price. In short, Canadian services suffer little from the Baumol disease when capital is taken into account. However, their share of domestic final demand does not keep pace with their employment and value added shares. Yet the service shares of domestic final demand do rise and this remains a puzzle to be explained. One explanation could be a shift of innovation towards services and, related to this, a shift of consumer preferences towards these new services. If $R \& D$ figures are anything to go by, they tend to bolster this explanation.

Mots Clés : Productivité, services, malaise de Baumol, innovation

Keywords: Productivity, services, Baumol disease, innovation

\footnotetext{
* Corresponding Author: Pierre Mohnen, CIRANO, 2020 University Street, 25 ${ }^{\text {th }}$ floor, Montréal, Qc, Canada H3A 2A5 Tel.: (514) 985-4028 Fax: (514) 985-4039 email: mohnenp@cirano.umontreal.ca Forthcoming in "The Growth of Service Industries: The Paradox of Exploding Costs and Persistent Demand", Ronald Schettkat and Thijs ten Raa (eds.), Edward Elgar, 2000. We thank the participants of the Amsterdam conference and an anonymous referee for helpful comments.

† Université du Québec à Montréal and CIRANO

Tilburg University
} 


\section{Introduction}

In a famous article of 1967, William Baumol predicted that services would price themselves out of the market, given their lower productivity growth and the consequent rise of their relative price, compared to non-service goods. Twenty years later, we observe that measured productivity growth in services is indeed relatively low, but that at the same time the modern economy is less manufacturing and more service based. Economic activity has substantially shifted away from manufacturing towards services, as it had moved from the primary sector to manufacturing in the first half of this century. How to reconcile these observations?

In this paper we examine the apparent paradox in the light of the Canadian experience. We first look at the facts. In section 2 , we trace productivity trends and employment shifts for the Canadian economy over the period 1962-1991. Second, we review a list potential explanations. Labor productivity growth provides only a partial picture of productivity performance since it ignores the role of capital accumulation, so we look at total factor productivity growth. In section 3, we distinguish between value-added and final demand. Their macro identity breaks down at the sectoral level and this has implications on the issue. Value added might be more concentrated in services than before, reflecting a crowding-out of services from manufacturing, and yet final demand composition has barely changed. We then examine shifts in final demand composition at both the commodity and final demand category levels. In section 4, we explore the hypothesis that Canadian services may have gained a comparative advantage in international trade. Last, but not least, production and final demand for services may have gained ground as a result of technical change. The verdict on the latter mechanism is provided in section 5 . We conclude in section 6 by summarizing the results of our analysis of the Canadian experience.

\section{Labour employment and productivity}

To assess the extent to which economic activity has shifted towards services and productivity in services is sluggish, we use the input-output data of the Canadian economy at the medium level of aggregation (50 sectors and 92 commodities) and the KLEMS database (Johnston, 1994 and Statistics 
Canada, various issues). We report results for ten groups of sectors: the primary sector, manufacturing, construction, transportation, communication, wholesale trade, retail trade, FIRE (finance, insurance and real estate), business services and personal services. ${ }^{1}$ We compare three periods, the 1960s, 1970s and 1980s, which are not exactly decades, but cover the periods 196274, 1975-81 and 1982-1991. The two years separating the periods are slump years. This choice enables us to compare productivity and employment as much as possible over comparable phases of the business cycles. Table 1 reveals the changing pattern of labor employment by sector. The big loosers are the primary sector and manufacturing. Their combined employment share has dwindled by 11.7 percentage points. Employment in services gone up, except for construction and transportation. The big winners are business and personal services with a surge in total employment share of 9.2 percentage point.

The shift of employment towards the services can to some extent reflect the stagnant productivity in services. The story is usually cast in terms of labor productivity. Table 2 shows real value-added per unit of labor for the ten groups of sectors and the three time-periods. Value-added is the value of the net output vector of commodities for a group of sectors. The figures are in $1986 \$ \mathrm{C}$ (anadian) per hour worked. Table 2 reveals the Baumol disease. The top five groups of sectors, the 'bolds-and-nuts' chamber of the Canadian economy, all show dramatic increases in real value-added per hour from the 1960s to the 1980s, ranging from $47 \%$ (in construction) to $103 \%$ (in communication). The bottom five groups of sectors, the 'soft' chamber of the economy (wholesale and retail trade, FIRE, and business and personal services), depict increases in real value-added per hour below the total economy's average over the same period, with personal services trailing at $3 \%$. At the M-level of aggregation, labor productivity growth is thus negatively correlated with employment growth. Services, except for construction and communication, display the greatest growth in employment but also the lowest growth in labor productivity.

Now, we know that labor productivity is not the ideal way to measure productivity since it relates output only to the labor input. A stagnant labor

\footnotetext{
${ }^{1}$ Sectors 41 to 50 were allocated to business or to personal services according to their ratio of shipments to domestic intermediate and final demand. Business services are characterized by a preponderance of deliveries to intermediate domestic demand.
} 
productivity is not a problem if labor substitutes for capital and the factor savings are just on another input. Table 3 reports the capital/labor ratios, also in 1986 \$C per personhour. All sectors but wholesale trade have increased their capital intensity. The question is whether the 'soft' part of the economy has done so at a lower pace and thereby compensated for its poorer labor productivity performance. The answer is 'yes' for retail trade and for business and personal services, but 'no' for FIRE. Because of the relative capital savings in at least four of these five sectors, the Baumol disease may be less severe if we measure the performance of sectors in terms of total factor productivity (TFP) instead of labor productivity. It can be shown that, under constant returns to scale, TFP growth is equal to labor productivity growth minus the growth in the capital/labor ratio multiplied by the cost share of capital.

Table 4 reports annualised TFP-growth rates for our ten groups of sectors over the three periods. The Canadian economy was healthy in all periods. In fact, the aggregate Solow residual, i.e. the Domar weighted averages of the sectoral Solow residuals, are $1.41,0.47$ and 0.17 respectively for the three periods. Notice the pervasive TFP slowdown between the 1960s and the 1980s, except for the primary sector, which went through a tremendous recovery in the 1980s. It is interesting to see that, with the exception of personal services, the weak services sectors that we have identified so far did not perform worse than manufacturing. In fact, Canadian manufacturing TFP-growth declined throughout the three periods. It even became negative in the 1980s. Personal services match this downward trend, but wholesale and retail trade, business services and FIRE outperformed manufacturing. As we suspected, the Baumol disease is more localized when measured in terms of total factor productivity growth. It mainly applies to personal services. Now that we have clarified the symptom, let us turn to some of the possible explanations.

\section{Value-added versus final demand}

Perhaps the clue in understanding the persistence of services is the presence of intermediate inputs. Most economic models treat sectors as production units that map factor inputs, labor and capital, into "output". Summation of these "outputs" over the sectors yields national product. In such a framework 
national product and income are equal, not only in the aggregate, but also sector by sector. The presence of intermediate inputs preserves the macroidentity between national product and national income, but invalidates it at the sectoral level. The contributions of services to the national product and national income differ.

To get a concise understanding of the issue, let $\left(u_{i j}\right)_{i=1, \ldots, n}$ be the $j=1, \ldots, m$

use table, where $n$ is the number of commodities and $m$ the number of sectors. Here $u_{i j}$ is the amount of commodity $i$ used by sector $j$. Similarly, let $\left(v_{j i}\right)_{j=1, \ldots, m}$ be the make table, where $v_{j i}$ is sector $j$ 's output of $i=1, \ldots, n$

commodity $i$. The use and make tables are the heart of the System of National Accounts. Subtracting the use table from the transposed make table one obtains the net output table, where the typical element is

$$
\begin{array}{cc}
\left(w_{i j}\right)_{i}=1, \ldots, n=\left(v_{j i}-u_{i j}\right) & i=1, \ldots, n \\
j=1, \ldots, m & j=1, \ldots, m
\end{array} .
$$

The dimension is commodity by sector. Column totals yield value-added by sector, while row totals yield final demand by commodity. Total valueadded equals total final demand, as the sum of the column totals must be equal to the sum of the row totals. This is the identity between national income and national product, but there is no need for an equality between any column total and any row total. In particular, the contributions of the services to value-added and final demand may differ. This is particularly true of the business services. Although value-added is high (a big column total), final demand may be negligible (a small row total). Many sectors outsource their service activities to the business service sector. As a result, a lot of activity gets carried out in the business service sector, creating valueadded. However, this sector does not produce many commodities for final demand. As said, most studies measure the contribution of services in terms of value-added, so it is of interest to contrast the latter with the contribution of services to final demand. Tables 5 and 6 show the shares of services in value-added and in final demand, respectively.

Table 5 confirms the growing importance of services as sources of earning. The primary sector and manufacturing saw their shares of real value-added substantially and continuously decline. Between the 1960s and the 1980s, 
roughly $8.3 \%$ of real value-added moved from agriculture and manufacturing towards the services. A continuous but less severe relative loss of activity took also place in construction, transportation and retail trade. Wheras personal services saw their relative value-added share increase only slightly, all other services, in particular FIRE and business services, became much more important in relative terms.

Table 6 shows the final demand shares for the commodity groups roughly corresponding to our ten groups of sectors. The correspondance is not exact, as sectors may be active in more than one line of products, but it is sufficiently close for comparison. The pattern is basically the same as for value-added, that is manufacturing shrinks and services expand. The shift of final demand towards services amounts to $5.3 \%$, which is three percentage points less than the shift of value-added. So indeed, the rise of the services in terms of commodities is not as dramatic as in terms of value-added. Among the services, construction, transportation, retail trade and personal services are the weakest growth performers. The increase in final demand for services is less pronounced when expressed in terms of the categories of final demand.

In table 7, consumption can be split into goods, housing and other services. Housing and other services together explain 3.6 percentage points of the shift in final demand towards services. Investment and government expenditures are not broken down into goods and services, which could in part explain the lower increase in services when analyzed in terms of categories of final demand. If we compare our results with those reported by Joe Mattey (in this volume), the apparent shift towards services in final demand is even less pronounced in the United States than in Canada.

However modest, it remains a fascinating challenge to explain the increase of the real share of services in final demand. As a first step towards solving the mystery of increasing demand for services, we must distinguish between domestic final demand and net exports. Table 8 shows the domestic final demand share for the ten commodity groupings. Compared to table 6 , it includes all final demand categories but net exports. The shift from the primary and secondary sectors of activity towards services is down to $4.4 \%$ only. This further reduction suggests to explore the possibility that the Baumol disease in Canada has been countered by a shift in comparative advantage towards services. 


\section{A shift in comparative advantage?}

Canada is a small, open economy. The output of services is determined not only by preference and technology, but also by the terms of trade. In other words, even when productivity developments are relatively unfavorable to services and shifts in the preferences of consumers are insufficient to counter this trend, the output of services may still be strong if the Canadian comparative advantage has shifted towards the production of services.

It is not easy to determine the comparative advantage of a national economy. The standard approach is to compare costs across countries, but there are two problems with this line of analysis. First, the observed costs reflect not only technology, but also market distortions, such as monopoly power, tariffs and rents resulting from barriers to entry or to trade. Second, the abundance of factor inputs co-determines the comparative advantage. Ricardian technology and Heckscher-Ohlin factor abundance effects are equally crucial in the determination of comparative advantage (Trefler, 1995). Leamer and Levinsohn (1995) note that empirical testing of comparative advantage along the Heckscher-Ohlin-Vanek theory of the factor content of trade requires independent data on endowments, technology and trade, but that one ingredient, usually technology, is missing in applied work. Instead, we have analyzed the optimal allocation of activity across sectors for the Canadian economy, given real input-output data describing the structure of domestic absorption and technology, given data on factor availabilities from Statistics Canada KLEM's database, and finally given proxies for world prices.

Formally, we maximize the level of domestic final demand (given the observed proportions across commodities), subject to the material balance, the labor, capital, and the balance of payment constraints. The latter constraint is evaluated at world prices. We equate the world prices with the U.S. prices, given that Canada is a small and open economy, and that most of Canadian trade is with the U.S. The maximization of the level of domestic final absorption subject to the aforementioned constraints constitutes a linear program. The shadow prices of the tradeable commodities can be shown to be proportional to the U.S. prices. The shadow prices of the factor inputs measure their productivities. The shadow prices of the nontradeable commodities are equal to their costs. The primal variables, the activity levels of the sectors, 
reveal the comparative advantages. They signal which sectors would expand or contract under perfectly competitive conditions and free trade. We have run the linear program for every year in the period 1962-1991. A shift of comparative advantage is indicated by (dis)activation of sectors. A fuller presentation of the model is contained in ten Raa and Mohnen (1998).

The pattern of comparative advantage is surprisingly stable, even at the medium level of aggregation comprising 50 sectors. Crude petroleum or pipeline transport enjoys a comparative advantage for all years but one. The industry of fabricated metal products enjoys a comparative advantage through 1988. Tobacco products and printing-publishing do so from 1981 onwards. All these primary and manufacturing sectors share the comparative advantage with essentially one service sector each year: first FIRE (the 1962-1972 period), then health services (the 1973-1980 period, except for 1976 when it is amusement and recreational services), and lastly travel, advertising and promotion (the 1981-1991 period), accompanied by accommodation and food services through 1988. There is no shift from the primary sectors and manufacturing towards services. We can therefore conclude that international trade cannot explain the persistence of Canadian activity in services.

\section{Technological change}

Another potential explanation for the shift of value added and final demand towards the service sectors is technological change. First, new products appear at a much faster rate than before and at affordable prices: videos, CDroms, laser disks, cellular phones, roller-blades, notebooks, scanners, and so on. Second, with these new products, entirely new services emerge. Think of video stores, computer stores, cybercafes, internet server providers, software companies, internet search companies, central alarm systems, new telecommunication companies and so on. Third, Information and Communication Technologies (ICT) have changed the way of doing business. Many tasks along the product value chain are now outsourced: advertising, programming, after-sales service, et cetera. New business units specialize in these tasks, which partially explains the rise in value-added in business services. By the pressure of competition and innovation in business services, companies specialize in their core activities and tend to outsource secondary activities, 
which they used to perform in-house. Even households switch from nonbusiness services to market services. Time is devoted to earn money and let the personal services sector perform part of the household chores, such as housekeeping, babysitting, financial planning and so on. Fourth, new products and services often carry higher value added, because of customer snobbishness, low competition at the beginning of the product life-cycle, product differentiation, tied-in sales, high income elasticities, and low substitution possibilities. Demand for old, but especially for new, services have a higher income elasticity than demand for traditional manufactured goods. Competition shifts value creation from the manufacturing stages towards the various stages of servicing, e.g. providing life-time service plans, product-life insurance contracts, purchase on credit options, car-leasing instead of car-selling. There might also be a saturation effect for manufactured goods whereas demand for services can be boundless. For example, a household's demand for cars is pretty dry after owning two or three cars, but demand for health services, leisure, or travel can increase by much more than a factor of two or three. Fifth, some companies producing manufactured goods have diversified into offering new services connected with their manufactured product. The service arm of the company may have grown so much that the whole company gets classified into services. ${ }^{2}$

To give some substance to the hypothesis of technological change, we examine in table 9 the sectoral evolution of R\&D stocks. Those stocks represent not yet obsolete stocks of knowledge accumulated from past R\&D expenditures. Although R\&D is only an input in the generation of technological change, it is one of the most revealing indicators of innovation. Table 9 shows that the proportion of total R\&D stock residing in manufacturing has sharply dropped from $91.1 \%$ in the 1960 s to $75.2 \%$ in the 1980 s. Manufacturing still remains the sector where most of R\&D is done, but services are rapidly gaining ground, especially in communication and in business and personal services. Since, as a first approximation, we can assume that the efficiency of converting R\&D into new products is the same in all industries, differential growth in R\&D stocks across sectors implies differential growth in economic activity across sectors.

\footnotetext{
${ }^{2}$ For more documentation on some of these dimensions of technological change and their impact on productivity and activity in services, see Neef (1998), Coyle (1999), and Shapiro and Varian (1999).
} 


\section{Conclusion}

The Canadian service sectors accounted, in the period spanning the three decades from 1961 to 1992, for an ever greater share of employment in the economy, even though their productivity growth was lower than in the primary sector and in manufacturing. To reconcile this apparent contradiction with the so-called Baumol disease, which predicts a decline in the share of services given their relative poor productivity performance and ensuing rising relative price, we have explored four potential explanations. First, the incorporation of capital in productivity analysis makes the disease less accute. Indeed, over this period annualized TFP growth rates were not worse in the two most expanding service sectors (FIRE and business services) than in manufacturing. Second, the proper accounting of intermediate inputs drives a wedge between the income and product shares of the services, rendering them less buoyant in terms of product share: for all service sectors combined, the real value-added share rose by 8.3 percentage points, whereas the commodity output share rose by only 5.3 percentage points. Third, limitation to domestic final demand shares makes the role of services become even more modest: an increase of only 4.4 percentage points. Fourth, and related to this, we found no validity to the argument that a shift in comparative advantage towards services may have countered the decline of services due to their higher relative prices. In short, Canadian services suffer little from the Baumol disease when capital is taken into account. However, their share of domestic final demand does not keep pace with their employment and value added shares. Yet the service shares of domestic final demand do rise and this remains a puzzle to be explained. One explanation could be a shift of innovation towards services and, related to this, a shift of consumer preferences towards these new services. If R\&D figures are anything to go by, they tend to bolster this explanation.

One final remark is in order. The very figures of labor productivity or total factor productivity in services might be seriously mismeasured. Services are hard to measure and for some of them good notions of output are not even available. Moreover, in the presence of technological change, quality improvements in services and the prices of entirely new services are even harder to measure correctly. It is very likely that services are undervalued as their output is often measured by their cost of production, given the lack of good price data and a proper definition of what services are actually supposed 
to measure. Hence it may well be that there is no real Baumol disease in services, as prices are rise by less and total factor productivity by more than what is actually measured in the official statistics.

\section{$7 \quad$ References}

Baumol, William, "Macroeconomics of Unbalanced Growth: The Anatomy of Urban Crisis", American Economic Review, 57, 415-26 (1967).

Coyle, Diane, The Weightless World, MIT Press, Cambridge, (1999).

Leamer, E.E. and J. Levinsohn, "International Trade Theory: the Evidence," in G. Grossman and K. Rogoff, eds., Handbook of International Economics, Vol. III, North-Holland, Amsterdam (1995).

Johnson, J., "Une base de données KLEMS décrivant la structure des entrées de l'industrie canadienne", Statistique Canada, Division des EntréesSorties, Cahier Technique \#73F (1994).

Mattey, Joe, "Will the New Information Economy Cure the Cost Disease in the US?", chapter 5 in this volume, (2000).

Neef, Dale (ed.), The Knowledge Economy. Butterworth-Heinemann, Boston, (1998).

Shapiro, Carl and Hal Varian, Information Rules, Harvard Business School Press, Boston, (1999).

Statistics Canada, System of National Accounts - The Input-Output Structure of the Canadian Economy, Minister of Supply and Services, Ottawa (various issues).

ten Raa, Thijs and Pierre Mohnen, "Sources of productivity growth: Technology, terms of trade, and preference shifts", CentER discussion paper \#98105, (1998).

Trefler, Daniel, "The Case of Missing Trade and Other Mysteries," American Economic Review, 85, 1029-1045, (1995). 
Table 1. Labor distribution (sectoral shares).

$\begin{array}{lrrrr}\text { Groups of sectors } & 1960 \mathrm{~s} & 1970 \mathrm{~s} & 1980 \mathrm{~s} & 80 \mathrm{~s}-60 \mathrm{~s} \\ & & & & \\ \text { Primary } & 15.4 \% & 11.8 \% & 9.8 \% & -5.6 \% \\ \text { Manufacturing } & 27.7 \% & 24.4 \% & 21.6 \% & -6.1 \% \\ \text { Construction } & 9.8 \% & 9.3 \% & 8.6 \% & -1.2 \% \\ \text { Transportation } & 6.4 \% & 6.3 \% & 5.8 \% & -0.6 \% \\ \text { Communication } & 3.1 \% & 3.6 \% & 3.5 \% & 0.4 \% \\ \text { Wholesale Trade } & 5.7 \% & 6.2 \% & 7.0 \% & 1.3 \% \\ \text { Retail Trade } & 14.3 \% & 15.2 \% & 14.9 \% & 0.6 \% \\ \text { FIRE } & 5.0 \% & 6.3 \% & 7.0 \% & 2.0 \% \\ \text { Business Services } & 4.2 \% & 6.8 \% & 9.6 \% & 5.4 \% \\ \text { Personal Services } & 8.4 \% & 10.1 \% & 12.2 \% & 3.8 \% \\ \text { Total Economy } & 100 \% & 100 \% & 100 \% & 0 \%\end{array}$

Note 1. The 1960s correspond to the period 1962-1974, the 1970s to 1975-1981, and the 1980s to 1982-1991.

Note 2. At the M-level of disaggregation, primary regroups sectors 1-7 and 39, manufacturing 8-28, construction 29, transportation 30-32, communications 33-34, wholesale trade 35, retail trade 36, FIRE 37, 38 and 40, business services 41, 47-50, and personal services 42-46. 
Table 2. Value-added/labor (1986\$C per hour)

$\begin{array}{lrrrr}\text { Groups of sectors } & 1960 \mathrm{~s} & 1970 \mathrm{~s} & 1980 \mathrm{~s} & 80 \mathrm{~s}-60 \mathrm{~s} \\ & & & & \\ \text { Primary } & 15.66 & 19.32 & 23.96 & +53 \% \\ \text { Manufacturing } & 17.37 & 22.63 & 26.47 & +52 \% \\ \text { Construction } & 17.60 & 21.90 & 25.83 & +47 \% \\ \text { Transportation } & 15.42 & 19.11 & 23.11 & +50 \% \\ \text { Communication } & 26.52 & 39.81 & 53.87 & +103 \% \\ \text { Wholesale Trade } & 16.32 & 19.01 & 22.32 & +37 \% \\ \text { Retail Trade } & 10.62 & 11.86 & 12.82 & +21 \% \\ \text { FIRE } & 58.52 & 64.08 & 70.30 & +20 \% \\ \text { Business Services } & 13.28 & 14.95 & 16.23 & +22 \% \\ \text { Personal Services } & 15.72 & 17.86 & 16.27 & +3 \% \\ \text { Total Economy } & 17.92 & 22.30 & 25.41 & +42 \%\end{array}$

Note. See table 1 for the definition of periods and sectors. 
Table 3. Capital-labor ratios (1986 \$C/hour).

$\begin{array}{lrrrr}\text { Groups of sectors } & 1960 \mathrm{~s} & 1970 \mathrm{~s} & 1980 \mathrm{~s} & 80 \mathrm{~s}-60 \mathrm{~s} \\ & & & & \\ \text { Primary } & 55.81 & 93.36 & 128.99 & +131 \% \\ \text { Manufacturing } & 31.75 & 43.48 & 58.41 & +84 \% \\ \text { Construction } & 5.71 & 7.90 & 11.41 & +100 \% \\ \text { Transportation } & 106.54 & 107.00 & 121.90 & +14 \% \\ \text { Communication } & 253.51 & 309.64 & 424.04 & +67 \% \\ \text { Wholesale Trade } & 12.33 & 11.92 & 11.76 & -5 \% \\ \text { Retail Trade } & 9.01 & 8.94 & 9.85 & +9 \% \\ \text { FIRE } & 35.45 & 52.52 & 86.17 & +143 \% \\ \text { Business Services } & 13.41 & 10.60 & 15.42 & +15 \% \\ \text { Personal Services } & 22.65 & 22.39 & 26.57 & +17 \% \\ \text { Total Economy } & 38.69 & 48.62 & 61.26 & +58 \%\end{array}$

Note. See table 1 for the definition of periods and sectors. 
Table 4. TFP-growth rates (annualized percentages).

$\begin{array}{lrrrr}\text { Groups of sectors } & 1960 \mathrm{~s} & 1970 \mathrm{~s} & 1980 \mathrm{~s} & 80 \mathrm{~s}-60 \mathrm{~s} \\ & & & & \\ \text { Primary } & -0.83 & -2.11 & 1.10 & +1.93 \\ \text { Manufacturing } & 0.94 & 0.16 & -0.20 & -1.14 \\ \text { Construction } & -0.17 & 1.92 & -0.39 & -0.22 \\ \text { Transportation } & 2.82 & 0.08 & 1.03 & -1.79 \\ \text { Communication } & 3.91 & 1.50 & 0.64 & -3.27 \\ \text { Wholesale Trade } & 2.04 & 1.39 & 0.98 & -1.06 \\ \text { Retail rade } & 1.58 & -0.16 & 0.81 & -0.77 \\ \text { FIRE } & 1.09 & 1.31 & 0.40 & -0.69 \\ \text { Business Services } & 0.48 & 0.62 & -0.12 & -0.60 \\ \text { Personal Services } & -0.12 & -1.02 & -1.87 & -1.75 \\ \text { Total Economy } & 1.41 & 0.47 & 0.17 & -1.24\end{array}$

Note. See table 1 for the definition of periods and sectors. 
Table 5. Real value-added distribution (sectoral shares, $1986 \$$ C).

$\begin{array}{lrrrr}\text { Groups of sectors } & 1960 \mathrm{~s} & 1970 \mathrm{~s} & 1980 \mathrm{~s} & 80 \mathrm{~s}-60 \mathrm{~s} \\ & & & & \\ \text { Primary } & 13.1 \% & 10.2 \% & 9.2 \% & -3.9 \% \\ \text { Manufacturing } & 26.8 \% & 24.7 \% & 22.4 \% & -4.4 \% \\ \text { Construction } & 9.6 \% & 9.1 \% & 8.7 \% & -0.9 \% \\ \text { Transportation } & 5.6 \% & 5.4 \% & 5.2 \% & -0.4 \% \\ \text { Communication } & 4.7 \% & 6.5 \% & 7.4 \% & +2.7 \% \\ \text { Wholesale Trade } & 5.2 \% & 5.3 \% & 6.2 \% & +1.0 \% \\ \text { Retail Trade } & 8.5 \% & 8.1 \% & 7.5 \% & -1.0 \% \\ \text { FIRE } & 16.2 \% & 18.1 \% & 19.4 \% & +3.2 \% \\ \text { Business Services } & 3.1 \% & 4.6 \% & 6.2 \% & +3.1 \% \\ \text { Personal Services } & 7.3 \% & 8.0 \% & 7.8 \% & +0.5 \% \\ \text { Total Economy } & 100 \% & 100 \% & 100 \% & 0 \%\end{array}$

Note. The 1960s correspond to the period 1962-1974, the 1970s to 19741981, and the 1980s to 1981-1991. For the groups of sectors see Table 1. 
Table 6. Final demand distribution (commodity shares, $1986 \$ \mathrm{C}$ ).

$\begin{array}{lrrrr}\text { Groups of commodities } & 1960 \mathrm{~s} & 1970 \mathrm{~s} & 1980 \mathrm{~s} & 80 \mathrm{~s}-60 \mathrm{~s} \\ & & & & \\ \text { Primary } & 2.7 \% & 1.6 \% & 3.1 \% & +0.4 \% \\ \text { Manufacturing } & 29.9 \% & 27.8 \% & 24.1 \% & -5.8 \% \\ \text { Construction } & 19.5 \% & 18.6 \% & 16.7 \% & -2.8 \% \\ \text { Transportation } & 2.5 \% & 2.4 \% & 2.3 \% & -0.2 \% \\ \text { Communication } & 2.5 \% & 3.5 \% & 4.1 \% & +1.6 \% \\ \text { Wholesale Trade } & 3.4 \% & 4.0 \% & 5.0 \% & +1.6 \% \\ \text { Retail Trade } & 8.4 \% & 8.7 \% & 8.5 \% & +0.1 \% \\ \text { FIRE } & 15.5 \% & 16.9 \% & 18.7 \% & +3.2 \% \\ \text { Business Services } & 5.4 \% & 5.7 \% & 6.7 \% & +1.3 \% \\ \text { Personal Services } & 10.2 \% & 10.9 \% & 10.7 \% & +0.5 \% \\ \text { Total Economy } & 100 \% & 100 \% & 100 \% & 0 \%\end{array}$

Note. At the M-level of disaggregation, primary corresponds to commodities 1-13 and 93-94, manufacturing to 14-69, construction to 70-72, transportation to $73-74$, communication to $75-79$, wholesale trade to 80 , retail trade 81 , FIRE to $82-83$, business services to 84 , part of $89,90-92$, and personal services $85-88$, part of 89 . For the definition of periods, see table 1 . 
Table 7. Final demand distribution by categories of final demand (category shares, $1986 \$ C$ ).

$\begin{array}{lrrrr}\text { Categories of final demand } & 1960 \mathrm{~s} & 1970 \mathrm{~s} & 1980 \mathrm{~s} & 80 \mathrm{~s}-60 \mathrm{~s} \\ & & & & \\ \text { Goods } & 40.6 \% & 38.9 \% & 35.5 \% & -5.1 \% \\ \text { Housing } & 11.3 \% & 12.3 \% & 14.1 \% & 2.8 \% \\ \text { Services other than housing } & 17.8 \% & 17.9 \% & 18.6 \% & 0.8 \% \\ \text { Investment } & 27.8 \% & 28.2 \% & 26.8 \% & -1.0 \% \\ \text { Government } & 5.0 \% & 6.6 \% & 7.5 \% & +2.5 \% \\ \text { Net trade } & -2.4 \% & -3.9 \% & -2.5 \% & -0.1 \%\end{array}$

Note. At the M-level of disaggregation, goods correspond to final demand categories 1-9, housing to 10 , services other than housing to 11 and 13 , investment to 14-23, government to 27 and 28, and net trade to 12, 24-26. For the definition of periods, see table 1 . 
Table 8. Domestic final demand distribution (commodity shares, 1986 $\$ C)$.

$\begin{array}{lrrrr}\text { Groups of commodities } & 1960 \mathrm{~s} & 1970 \mathrm{~s} & 1980 \mathrm{~s} & 80 \mathrm{~s}-60 \mathrm{~s} \\ & & & & \\ \text { Primary } & 2.3 \% & 2.3 \% & 2.2 \% & -0.1 \% \\ \text { Manufacturing } & 32.9 \% & 31.3 \% & 28.6 \% & -4.3 \% \\ \text { Construction } & 19.1 \% & 17.6 \% & 16.2 \% & -2.9 \% \\ \text { Transportation } & 1.9 \% & 1.9 \% & 2.0 \% & +0.1 \% \\ \text { Communication } & 2.4 \% & 3.1 \% & 3.8 \% & +1.4 \% \\ \text { Wholesale Trade } & 2.7 \% & 3.2 \% & 4.0 \% & +1.3 \% \\ \text { Retail Trade } & 8.2 \% & 8.3 \% & 8.2 \% & 0 \% \\ \text { FIRE } & 15.5 \% & 16.5 \% & 18.7 \% & +3.2 \% \\ \text { Business Services } & 5.1 \% & 5.5 \% & 5.8 \% & +0.7 \% \\ \text { Personal Services } & 10.0 \% & 10.4 \% & 10.5 \% & +0.5 \% \\ \text { Total Economy } & 100 \% & 100 \% & 100 \% & 0 \%\end{array}$

Note. For the definition of commodities and periods, see table 6 . 
Table 9. R\&D stock distribution (sectoral shares, $1986 \$ C$ ).

$\begin{array}{lrrrr}\text { Groups of sectors } & 1960 \mathrm{~s} & 1970 \mathrm{~s} & 1980 \mathrm{~s} & 80 \mathrm{~s}-60 \mathrm{~s} \\ & & & & \\ \text { Primary } & 4.6 \% & 5.9 \% & 5.3 \% & +0.7 \% \\ \text { Manufacturing } & 91.1 \% & 84.3 \% & 75.2 \% & -15.9 \% \\ \text { Construction } & 0.1 \% & 0.1 \% & 0.2 \% & +0.1 \% \\ \text { Transportation } & 0.6 \% & 1.2 \% & 0.8 \% & +0.2 \% \\ \text { Communication } & 1.8 \% & 5.0 \% & 7.2 \% & +5.4 \% \\ \text { Wholesale Trade } & 0.1 \% & 0.2 \% & 0.8 \% & +0.7 \% \\ \text { Retail Trade } & 0.1 \% & 0.2 \% & 0.8 \% & +0.7 \% \\ \text { FIRE } & 0.4 \% & 0.7 \% & 2.3 \% & +1.9 \% \\ \text { Business Services } & 0.6 \% & 1.2 \% & 3.8 \% & +3.2 \% \\ \text { Personal Services } & 0.6 \% & 1.2 \% & 3.8 \% & +3.2 \% \\ \text { Total Economy } & 100 \% & 100 \% & 100 \% & 0 \%\end{array}$

Note. For a definition of sectors and periods, see table 1. 


\section{Liste des publications au CIRANO *}

\section{Cahiers CIRANO / CIRANO Papers (ISSN 1198-8169)}

99c-1 Les Expos, l'OSM, les universités, les hôpitaux : Le coût d'un déficit de 400000 emplois au Québec — Expos, Montréal Symphony Orchestra, Universities, Hospitals: The Cost of a 400,000-Job Shortfall in Québec / Marcel Boyer

96c-1 Peut-on créer des emplois en réglementant le temps de travail? / Robert Lacroix

95c-2 Anomalies de marché et sélection des titres au Canada / Richard Guay, Jean-François L'Her et Jean-Marc Suret

95c-1 La réglementation incitative / Marcel Boyer

94c-3 L'importance relative des gouvernements: causes, conséquences et organisations alternative / Claude Montmarquette

94c-2 Commercial Bankruptcy and Financial Reorganization in Canada / Jocelyn Martel

94c-1 Faire ou faire faire : La perspective de l'économie des organisations / Michel Patry

\section{Série Scientifique / Scientific Series (ISSN 1198-8177)}

2000s-09 Nouvelle économie, nouvelle organisation et technologies de l'information / Suzanne Rivard

2000s-08 Semi-Stationary Equilibrium in Leader-Follower Games / Ngo Van Long et Koji Shimomura

2000s-07 Strategic Behavior under Intertemporal Production Externalities / Richard Cornes, Ngo Van Long et Koji Shimomura

2000s-06 Preemption and Rent Dissipation with Multiple Investments / Marcel Boyer, Pierre Lasserre, Thomas Mariotti et Michel Moreaux

2000s-05 A Monte-Carlo Method for Optimal Portfolios / Jérôme Detemple, René Garcia et Marcel Rindisbacher

2000s-04 Cooperation in Public Goods Experiments / Claudia Keser (with comment by Claude Montmarquette)

2000s-03 The Illusion of Trust and Performance / Benoit A. Aubert et Barbara L. Kelsey

2000s-02 Risques à grande échelle dans les systèmes en réseau : quelques interrogations / Erwann Michel-Kerjan

2000s-01 Wealth Distribution, Moral Hazard, and Entrepreneurship / Sanjay Banerji et Ngo Van Long

99s-48 A New Class of Stochastic Volatility Models with Jumps: Theory and Estimation / Mikhail Chernov, A. Ronald Gallant, Eric Ghysels et George Tauchen

99s-47 Latent Variable Models for Stochastic Discount Factors / René Garcia et Éric Renault

\footnotetext{
* Vous pouvez consulter la liste complète des publications du CIRANO et les publications elles-mêmes sur notre site Internet à l'adresse suivante :
}

http://www.cirano.umontreal.ca/publication/documents.html 